Article

\title{
Allocation of Energy Saving Target for Provinces Based on Cluster Analysis in Vietnam
}

\author{
Dinh Van Chau ${ }^{1,2 *}$ \\ 1 Faculty of Engineering Physics and Nanotechnology, University of Engineering and Technology, Vietnam \\ National University, Hanoi, Vietnam; dinhchau@vnu.edu.vn \\ 2 2Dept. Energy Efficiency and Sustainable Development, Ministry of Industry and Trade, Vietnam; \\ chaudv@moit.gov.vn \\ * Correspondence: vanchaudinh@gmail.com; Tel: +84-9142-626-66.
}

\begin{abstract}
In order to meet the national energy saving goals set in the Vietnam National Energy Efficiency Program in the period of 2019 - 2030 (VNEEP), the Vietnamese government has adopted a series solutions and policies to improve energy efficiency. The Vietnam's 63 provinces will be as main actor for the national achievement in energy efficiency. Thus, understanding the province's potentiality of energy efficiency is useful for the harmonious and sustainable development between the economy and energy systems. In this study, provincial and national data from General Statistic Office are analyzed in terms of the energy efficiency levels. With the trends of economic development and energy consumption in both national and regional levels, the Lorenz curve between Vietnamese energy consumption and GDP is investigated. The Lorenz coefficient shows the energy allocation is nether reasonable nor balanced. By using clustering method, the 63 provinces of Vietnam clustered into 7 groups that the provinces in the cluster has the similar indexes of energy efficiency i.e. ability, responsibility, potential and difficulty. The energy consumption and GDP are predicted in the period of 2019 - 2025. Based on the difference of GDP development and energy consumption levels, the target of energy efficiency for each province through clustering is set. The results show that 33 provinces included in the cluster 1, 2, 3, 4 and 6 are heavy contribution. Among them, the provinces in the cluster 2 and 3 need to focus on the industry sector in their energy saving policy. The cluster 7 included the under-developed provinces can learn development's experiences of the provinces in the cluster 1,2, 3 and 4 to find the best way of their future development.
\end{abstract}

Keywords: energy efficiency; clustering analysis; allocation target; Vietnam

\section{Introduction}

An overarching goal of Vietnam's National Energy Efficiency Program period of 2019-30 (VNEEP) is to address energy in tandem with economy development [1]. Specific goal includes: (i) Mobilizing all domestic and international resources to promote EE\&C through synchronous implementation of state management tasks and measures, technical assistance, scientific and technology research and product development, market transformation, training and development of human resources, making use of experience and support of the international community in the EE\&C sector; (ii) Forming the EE\&C habit in every social activity; reducing energy intensity in various professions, economic sectors; energy efficiency becoming the frequent activity for designated energy users and key energy-intensive economic sectors; orienting towards the green growth and sustainable development. In line with these goals, the central government chose to set targets under the metric of $8.0-10 \%$ energy saving based on the prediction of total energy consumption requested for economic development in the period. The VNEEP divided into 2 stages, in which, the first stage is in period of $2019-2015$ with $5.0 \%$ saving energy.

To achieve a national target, targets are allocated sub-nationally to provinces, cities, sectors, and enterprises. For the VNEEP, a province's target is set in the Province's Action plan on energy efficiency. In a strong effort to meet the target, provinces need to use a more scientific methodology 
to better estimate the varying potential for energy saving across the provinces, and to facilitate a change in development mode, as well as to achieve an equitable distribution of targets.

Overall national-level targets are allocated to sub-sets of the economy (e.g. provinces, economic sectors) through a variety of approaches. Target may be distributed relatively evenly among the chosen sub-set, based on equal percent reduction. Target allocation can use assessment of energy efficiency potential in each sub-set of the economy to provide guidance, or use more complex allocation methodologies that apply varying criteria for different economic sectors. For example, in China, China's national-level target to reduce energy use per unit of GDP by $20 \%$ during the 11th FYP was allocated to each province through a process in which the target was divided relatively evenly between provinces [2]. The central government requested that each province propose its own target. Most provinces proposed a 20\% target in line with the national target, although some proposed higher and others proposed lower targets. After some negotiation, the State Council approved the provincial targets. In the UK, the process for setting the Climate Change Agreement targets began with information-gathering on the part of the government [3]. The government obtained information regarding energy efficiency potential in energy-intensive industries through the Energy Efficiency Best Practices Program which produced good practice guides and case studies, new practice case studies, and information on future practices as well as through a report on projections of industrial sector carbon dioxide emissions under a business-as-usual scenario as well as two scenarios that included all cost-effective and all technically-possible technologies [4]. Then, for the ten largest energy-consuming sectors, individual companies made estimates of what energyefficiency improvements they were willing to commit to be based on an assessment of their potential and provided this information to their trade associations. More complex allocation method using multiple criteria applied to set targets is the "Triptych approach". This method used to establish the European Union's Kyoto Protocol negotiation target, divided the overall greenhouse gas (GHG) emissions target between the 15 countries that made up the EU at that time $[5,6]$. The approach focused on three key energy-consuming sectors of the economy: industry, electricity, and domestic (buildings and transportation) sectors. The allowance for industry was determined by projecting physical activity at an average of $1.2 \%$ per year $(2.1 \%$ per year in countries with GDP/capita less than $75 \%$ of EU average and $1.1 \%$ for other member countries), assuming that de-carbonization of fuels in industry increased $0.17 \%$ per year, and that energy efficiency improved $1.5 \%$ per year for all countries. The allowance for electricity took country-specific conditions, such as opposition to nuclear power, into account and assumed electricity growth would be limited to $1 \%$ per year for EU overall ( $1.9 \%$ for countries with GDP/capita is less than $75 \%$ of EU average and $0.9 \%$ for other countries). The allowance for the remaining more domestically oriented sectors (residential, transport, services) was based on projected population values and an assumption that there would be convergence to similar living conditions among countries by 2030 . This meant that per capita emissions for all EU member states were assumed to be equal in 2030 at a level below current levels, in line with general assessments of emission reduction potentials in these sectors (at EU level). The base year (1990) per capita emissions were then extrapolated to 2030 and multiplied with 2010 population levels to determine the 2010 allowance. Domestic sector energy values were climate-corrected to account for different heating and cooling energy needs among countries. The sectoral allowances were then combined to set a total target for each country, such that the overall EU target could be met. Other allocation methods include distributing a target to sub-regions based on one main indicator, such as GDP per capita, or distributing the target based on equal cost or cost optimization. Other multicriteria decision analysis methods can also be used, such as Analytic Hierarchy Process (AHP), or Cluster Analysis. Decision-makers identify the criteria and assign subjective ranking to them. Because some important criteria are hard to quantify, expert judgment supplements the quantitative analysis. Criteria such as "capability" or "innovation potential" or "leadership" can be assigned quantitative values and used along with reported data on energy consumption and economic structure. The combined effect of the criteria and their rankings are calculated and yield a preferred option. In China, the Central government in the 12th Five-Year Plan, allocated the reduction of energy intensity target to provinces by taking a two procedure: grouping the provinces into different clusters at first and then assigned reduction target to each cluster. In this allocation plan of the energy intensity 
target, the 31 Chinese provinces are divided into 5 clusters with reduction form of 5 levels ranging from $10 \%$ to $18 \%$.

This paper adopts the cluster analysis in multivariate statistical analysis to group the 63 Vietnamese provinces into clusters based on provincial similarities in economic, emissions, and reduction potential. Then energy saving targets are assigned to each cluster according to the equity or efficiency principle, and allocation results and policy implications are also discussed. This allocation method emphasizes the major differences between regional clusters while it ignores the minor differences within each cluster.

\section{Data and methodology}

\subsection{Indicator selection and cluster analysis method}

Allocation principles in energy efficiency efforts are often based on economic ability, energy consumption levels and energy saving potential. Indicators should be selected to reflect the characteristics of different provinces, especially the characteristics of energy consumption and energy conservation. There are four categories of the indicators used in the study (Table 1). The first category includes indicators reflecting the responsibility of energy conservation. If the total economic volume and energy consumption of the region are large, the responsibility of energy conservation is heavy. The second category includes the indicators reflecting the energy conservation potential or difficulty, which can take into account the energy intensity, industrial structure, urbanization rate and other indicators. The third category includes the indicators reflecting the energy conservation ability. The indicators reflect regional economic development and regional financial strength.

Table 1. List of the indicator for provincial clustering

\begin{tabular}{|c|c|c|c|}
\hline No. & Category & Indicator & Explanation \\
\hline 1. & \multirow{5}{*}{ Responsibility } & $\begin{array}{l}\text { The proportion of } \\
\text { energy consumption } \\
\text { (PEC) }\end{array}$ & $\begin{array}{l}\text { Reflecting the contribution to the } \\
\text { achievement of national targets }\end{array}$ \\
\hline 2. & & $\begin{array}{l}\text { Proportion of GDP } \\
\text { to the country } \\
\text { (PGDP) }\end{array}$ & $\begin{array}{l}\text { Reflecting the contribution to the } \\
\text { national GDP }\end{array}$ \\
\hline 3. & & $\begin{array}{l}\text { Per capita energy } \\
\text { consumption (PCEC) }\end{array}$ & $\begin{array}{l}\text { Reflecting the level of energy } \\
\text { consumption }\end{array}$ \\
\hline 4. & & $\begin{array}{l}\text { The proportion of } \\
\text { industrial added } \\
\text { value to GDP }(\mathrm{PI})\end{array}$ & $\begin{array}{l}\text { Reflecting the contribution to the } \\
\text { provincial GDP }\end{array}$ \\
\hline 5. & & $\begin{array}{l}\text { Regional GDP } \\
\text { growth rate } \\
\text { (RGDPGR) }\end{array}$ & Reflecting the rate of development \\
\hline 6. & \multirow{2}{*}{ Potential } & $\begin{array}{l}\text { Energy consumption } \\
\text { per unit GDP, } \\
\text { kgOE/VND mil. } \\
\text { (ECPGDP) }\end{array}$ & $\begin{array}{l}\text { Reflecting the potential of energy } \\
\text { conservation. }\end{array}$ \\
\hline 7. & & $\begin{array}{l}\text { Energy consumption } \\
\text { per unit of Industrial } \\
\text { Value Added } \\
\text { (ECPIGDP) }\end{array}$ & $\begin{array}{l}\text { Reflecting the potential of energy } \\
\text { conservation in industry }\end{array}$ \\
\hline
\end{tabular}


8.

The proportion of the third industry(or second industry) of GDP (3rdIPGDP)
Reflecting economic structure, the high proportion of industry, the potential of energy conservation is relatively large.

\begin{tabular}{|c|c|c|c|}
\hline 9. & & $\begin{array}{l}\text { GDP per capita } \\
\text { (PCGDP) }\end{array}$ & $\begin{array}{c}\text { Reflect the level of economic } \\
\text { development }\end{array}$ \\
\hline 10. & Ability & $\begin{array}{l}\text { Proportion of local } \\
\text { financial expenditure } \\
\text { to the country (PFE) }\end{array}$ & Reflecting the financial strength \\
\hline 11. & & $\begin{array}{l}\text { Investment in fixed } \\
\text { assets (IFA) }\end{array}$ & Reflecting the financial strength \\
\hline 12. & Difficulty & $\begin{array}{l}\text { Urbanization rate } \\
\text { (UR) }\end{array}$ & $\begin{array}{l}\text { Reflecting the change of residential } \\
\text { energy consumption }\end{array}$ \\
\hline
\end{tabular}

Based on the 12 indicators above, the cluster analysis as a multi-variate statistical analysis is applied to group the similar provinces into clusters. Cluster analysis methods fall into two categories: hierarchical cluster methods and non-hierarchical cluster methods. Following suggestions from related researches $[7,8,9]$, this study adopts a two-step procedure: the hierarchical cluster method is first employed to establish the proper number of clusters, then the cluster centroids from the first step are used as the initial condition of a non-hierarchical cluster method, which helps to fine-tune the results from the hierarchical cluster method.

For the first step of hierarchical cluster analysis, the method of Ward [10] is selected because it outperforms other hierarchical cluster methods when outliers are absent [7]. Some researches on regional cluster analysis also suggest that Ward's method gives the best interpretative solution [8;9]. In Ward's method, the union of two clusters occurs when it results in minimum information loss, which is measured by an increase in error sum of squares (S). If there are $n$ clusters, and Sk is the error sum of squares for the kth cluster, then:

$$
S_{k}=\sum_{i=1}^{n_{k}}\left(x_{i}-\overline{x_{k}}\right)^{\prime}\left(x_{i}-\overline{x_{k}}\right)
$$

where $n_{k}$ is number of provinces in the kth cluster, $x_{i}$ is a column vector comprising the 12 indicators of $i_{\text {th }}$ province, $\overline{x_{k}}$ is the centroid of the $k_{t h}$ cluster (averages of provinces within this cluster). Total error sum of square is defined as:

$$
S=\sum_{j=1}^{n} S_{j}
$$

In each step, every possible fusion of two clusters is considered and the pair of clusters which lead to the least increase in $S$ will be united. In the second step, the number and centroids of clusters generated from Ward's method are used as initial conditions for the K-means non-hierarchical method [11]. The procedure is as follows: (i) definition of $\mathrm{k}$ initial cluster centroids; (ii) an observation is assigned to the nearest cluster, followed by a recalculation of the new cluster centroid; (iii) repeating step 2 until the results remain unchanged.

\subsection{Allocation method}

Here, $G_{i}$ is defined as the reduction target for the ith cluster of province, $G_{i}$ is computed as follows: 


$$
G_{i}=a \times W_{i} \quad(\text { Eq.2) }
$$

where $\mathrm{a}$ is an adjustment coefficient $(\mathrm{a}>0)$; and $\mathrm{Wi}$ is the weight for the ith cluster $(0<\mathrm{Wi}<1)$; The relationship between provincial and nation energy efficiency target is calculated as follows:

$$
E C_{y}=\sum_{i=1} \frac{Y_{i, \mathrm{y}}}{Y_{y}} \times E C_{i, \mathrm{y}}
$$

where $\mathrm{EC}_{\mathrm{i}, \mathrm{y}}$ and $\mathrm{EC}_{\mathrm{y}}$ are the energy consumption of the ith cluster and of the whole nation in $\mathrm{y}$ year, respectively. $Y_{i, y}$ and $Y_{y}$ are the GDP of the ith cluster and of the whole nation in y year, respectively. In Eq. (3) the energy consumption of the ith cluster and of the whole nation in y year can be computed from their respective values in the period of $2011-2018$ using historical trend and the reduction targets (this study is based on the 5\% national energy consumption reduction target):

$$
E C_{y} \times(1-5 \%)=\sum_{i=1} \frac{Y_{i, \mathrm{y}}}{Y_{y}} \times E C_{i, \mathrm{y}} \times\left(1-a \times W_{i}\right)
$$

This equation indicates that the GDP of the nation and each province should be forecasted first in order to determine the value of a. Then the reduction targets (Gi) of each cluster can be computed from Eq. (2). Finally, Wi determines the relative value of the reduction target of each cluster, and is calculated as follows:

$$
W_{i}=\sum_{j}^{12} \alpha_{j} \times \frac{X_{i, j}}{X_{j, \max }}
$$

where, $X_{j, \max }(j=1,2, \ldots, 12)$ represents the maximum value of the $j$ th indicator in all regions; $X_{i, j}$ $(j=1,2, \ldots, 12)$ represents the mean value of the $j$ th indicator for the $i$ th cluster; $\alpha j$ is the weight for each indicator, which approves $\sum_{j}^{12} \alpha_{j}=1$. The value of $\alpha \mathrm{j}$ is based on different allocation principles.

\subsection{Allocation principles}

The allocation target based on each province's potential for energy saving, along with consideration of economic development level. It considers equity based on past performance and potential for improvement. The target allocation takes into account the historical variation in energy consumption trends among the provinces, and applies similar energy consumption trends for the years of the first stage of the VNEEP $(2019$ - 2025). Provincial energy trends are assumed to remain similar (e.g., fast-growing provinces still grow faster than slow-growing provinces). The rate of economic (GDP) growth was assigned to each province based on its growth rate trend in the past with an adjustment referring to the national growth rate.

Since this is a methodology for allocating a national target among the provinces, the analysis combines top-down national projections with bottom-up provincial in terms of energy and GDP to determine provincial intensity targets that will meet the national target. In other words, based on a chosen national intensity target level, iterative calculations are done on the provincial levels to determine provincial targets. Because the methodology is developed for the implementation of the VNEEP, it focuses on the years 2019 to 2025, with 2017 as the base year.

The methodology has three main steps:

Step 1. Project National-Level Values to 2025.

Step 2. Project Provincial-Level Energy and GDP Values to 2025.

Step 3. Calculate Provincial energy saving Target Allocations.

The adjustment of targets is a process of trial and error until a satisfactory allocation scheme is obtained. In addition, special circumstances should be taken into account in the adjustment of targets. It depends on the actual situation of the country and the regions. Allocation schemes can also be used as a basis to negotiate with regions. 
When adjusting the targets, it should be paid enough attention to the balance between the realization of regional goals and the realization of national goals. Usually for the target of energy consumption reduction rate, the trial calculation is carried out by adjusting one percent point upward or downward each time until the ideal result is obtained.

\subsection{Data sources}

The economic development and energy consumption in Vietnam's 63 provinces were taken based on statistics in period of 2011 - 2018 from the General Statistic Office, Ministry of Plan and Investment, Vietnam.

\section{Results}

\subsection{Energy efficiency development analysis}

The development trends of the economy and the energy consumption in recent years is considered as main factors affect the energy efficiency of national and provincial level. Figure 1 shows the total economic development and energy consumption in Vietnam form 2011-2018.

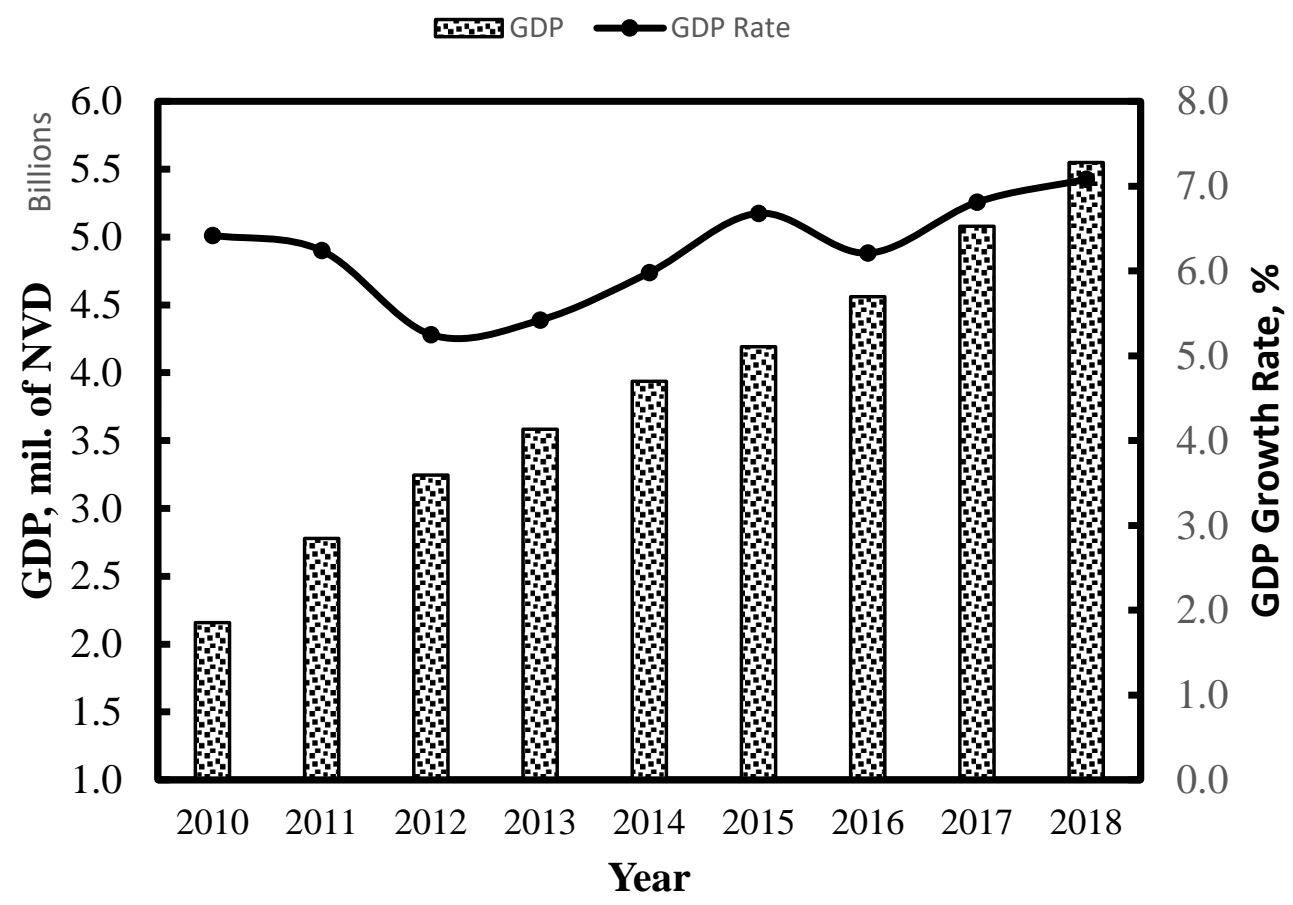

Figure 1. The total economy development and GDP's growth rate of Vietnam from $2010-2018$

It can see that the tendency of economy development in Vietnam is considerably in the period of 2011 - 2018. The total GDP of Vietnam was just 2.1 million of VND billion in 2011 but in 2018, it reached 5.5 million of VND billion, about 2.6 times expanded. Vietnamese economic growth remained in stable at the range of $5.0-7.0 \%$ in the period. The rate is highest in 2018 with $7.08 \%$, appositionally to the global economic growth rate. Influences of the changes in the Vietnamese government policy for restructure of economy may attribute to the stability of the GDP's growth rate.

With the high growth of the Vietnamese economy, the demand for energy is also increasing. The energy consumption in the period of 2011 - 2018 is shown in Figure 2 confirmed that the energy consumption increased consistent with economic development. In 2018, the total energy consumption reached 62.59 million of TOE increases $32 \%$ in comparison with the consumed energy amount in 2011. Under the guidance of energy conservation and energy efficiency policies, there was an improvement of energy efficiency. The energy intensity index decreased in the period, from 17.44 
$\mathrm{kgOE} / \mathrm{mil}$. of VND to $11.28 \mathrm{kgOE} / \mathrm{mil}$. of VND. (see Figure 2). In the period, the reduction of the energy intensity is about $65 \%$.

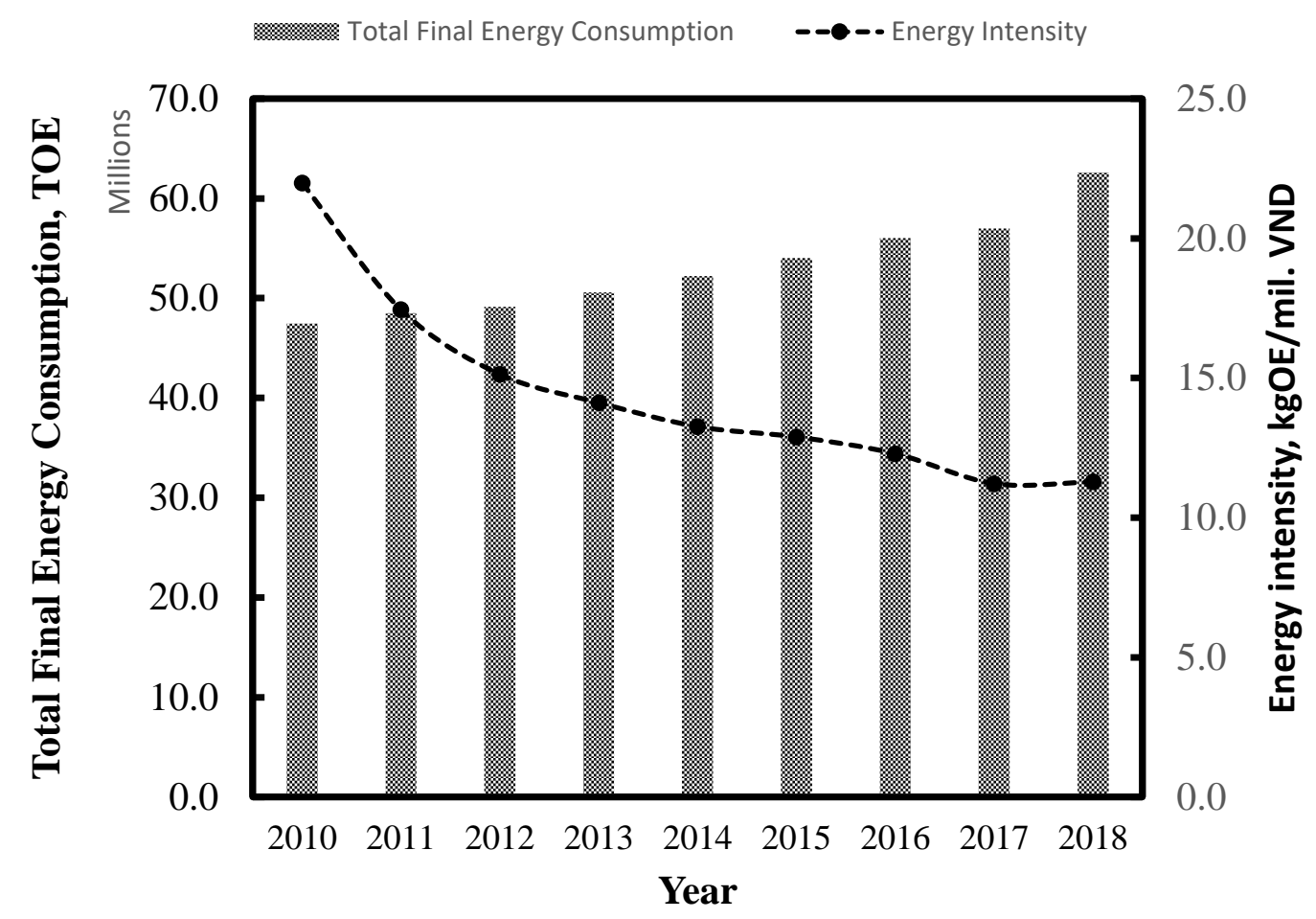

Figure 2. Vietnam's energy consumption and energy intensity from 2010 - 2018

In Vietnam, the energy resources and the energy demand are distributed reversely. The imbalanced distribution is also a cause for different energy efficiency levels in different provinces. Through the economic development and energy consumption analysis, the fitting method of the Lorenz curve is employed to explain the relationships between energy consumption and GDP development levels in recent years. With the application of the Lorenz theory, it can represent the energy allocation situation in different provinces and also show the national energy allocation situation in different years. The overall energy allocation situation in recent years will be explored and presents in Figure 3.

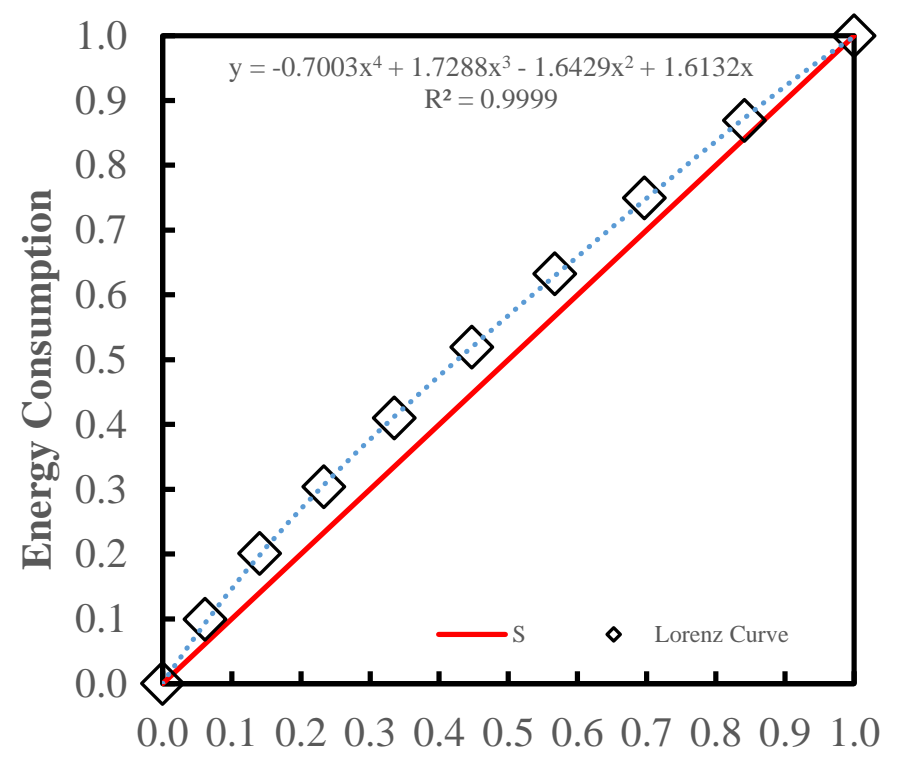

GDP 
Figure 3. The Lorenz curve of Vietnam's energy consumption and GDP from 2010 - 2018

The $S$ line in Figure 3 stands for absolute equality which is an ideal energy allocation situation. The fitted curve shows a polynomial relationship between the accumulative values of GDP and final energy consumption in the period of 2010 - 2018. It can see that the Lorenz curve is a convex above the $S$ line which resulted from the more consumed energy than the output of GDP meaning that the low energy efficiency level in the period. The area between the Lorenz curve and the absolute equality line is 0.0511 said as Lorenz coefficient represents the overall wastage caused by inefficiency allocation since the energy allocation in Vietnam was nether reasonable nor balanced. The extensive economic development and the imbalance between the energy supply and -demand can be considered as the main reasons for the low energy allocation efficiency. Based on this circumstance, it should improve the national energy intensity as the main way of energy saving allocation for the provinces.

\subsection{Cluster analysis}

In order to eliminate the effects of different scales, the cluster analysis is carried out with standardized variables. Table 3 shows the indicator values as input for clustering. It takes note that the original data collected in the series of Statistical Yearbook for national and provincial level in period of 2011-17 published by General Statistics Office of Vietnam.

Table 2. Indicator value for provincial cluster analysis

\begin{tabular}{|c|c|c|c|c|c|c|c|c|c|c|c|c|}
\hline \multirow{2}{*}{$\begin{array}{l}\text { Province } \\
\text { Name }\end{array}$} & \multicolumn{5}{|c|}{ Responsibility } & \multicolumn{3}{|c|}{ Potential } & \multicolumn{3}{|c|}{ Ability } & \multirow{2}{*}{$\begin{array}{c}\text { Difficulty } \\
\text { UR }\end{array}$} \\
\hline & PEC & $\begin{array}{l}\text { PG } \\
\text { DP }\end{array}$ & PCEC & $\begin{array}{l}\text { RGD } \\
\text { PGR }\end{array}$ & PI & $\begin{array}{l}\text { ECP } \\
\text { GDP }\end{array}$ & $\begin{array}{l}\text { ECPI } \\
\text { GDP }\end{array}$ & $\begin{array}{l}3 \text { rdIP } \\
\text { GDP }\end{array}$ & PFE & IFA & $\begin{array}{l}\text { PCG } \\
\text { DP }\end{array}$ & \\
\hline Ha Noi & 0.12 & 0.11 & 0.87 & 0.09 & 0.33 & 0.01 & 18.46 & 0.64 & 0.10 & $308,219,000$ & 85.97 & 0.49 \\
\hline Vinh Phuc & 0.01 & 0.01 & 0.67 & 0.08 & 0.60 & 0.01 & 10.32 & 0.32 & 0.02 & $28,229,259$ & 79.05 & 0.23 \\
\hline Bac Ninh & 0.02 & 0.03 & 1.16 & 0.19 & 0.74 & 0.01 & 8.90 & 0.23 & 0.01 & $119,257,000$ & $\begin{array}{c}133.3 \\
3 \\
\end{array}$ & 0.26 \\
\hline $\begin{array}{l}\text { Quang } \\
\text { Ninh }\end{array}$ & 0.03 & 0.02 & 1.18 & 0.10 & 0.57 & 0.01 & 10.61 & 0.36 & 0.03 & $60,597,259$ & $\begin{array}{c}103.0 \\
4\end{array}$ & 0.64 \\
\hline Hai Duong & 0.02 & 0.02 & 0.61 & 0.09 & 0.54 & 0.01 & 15.80 & 0.34 & 0.02 & $37,016,000$ & 50.30 & 0.25 \\
\hline Hai Phong & 0.05 & 0.03 & 1.38 & 0.14 & 0.42 & 0.02 & 16.56 & 0.53 & 0.02 & $71,874,346$ & 82.98 & 0.47 \\
\hline Hung Yen & 0.02 & 0.01 & 0.87 & 0.08 & 0.56 & 0.02 & 29.50 & 0.32 & 0.01 & $31,188,080$ & 49.38 & 0.13 \\
\hline Thai Binh & 0.02 & 0.01 & 0.69 & 0.10 & 0.33 & 0.02 & 41.30 & 0.36 & 0.01 & $51,308,565$ & 37.25 & 0.11 \\
\hline Ha Nam & 0.01 & 0.01 & 0.68 & 0.11 & 0.60 & 0.01 & 19.08 & 0.30 & 0.01 & $23,499,246$ & 48.61 & 0.16 \\
\hline Nam Dinh & 0.01 & 0.01 & 0.44 & 0.07 & 0.37 & 0.02 & 26.65 & 0.41 & 0.01 & $29,565,705$ & 28.29 & 0.18 \\
\hline Ninh Binh & 0.02 & 0.01 & 1.10 & 0.08 & 0.39 & 0.03 & 49.06 & 0.48 & 0.01 & $23,846,935$ & 44.28 & 0.21 \\
\hline Ha Giang & 0.00 & 0.00 & 0.07 & 0.07 & 0.22 & 0.00 & 9.41 & 0.47 & 0.01 & $7,094,614$ & 22.35 & 0.15 \\
\hline Cao Bang & 0.00 & 0.00 & 0.12 & 0.07 & 0.22 & 0.00 & 16.50 & 0.53 & 0.02 & $7,335,759$ & 24.47 & 0.23 \\
\hline Bac Kan & 0.00 & 0.00 & 0.31 & 0.05 & 0.15 & 0.01 & 67.09 & 0.52 & 0.01 & $4,289,017$ & 27.82 & 0.19 \\
\hline $\begin{array}{l}\text { Tuyen } \\
\text { Quang }\end{array}$ & 0.00 & 0.00 & 0.17 & 0.09 & 0.25 & 0.01 & 16.43 & 0.48 & 0.01 & $6,966,859$ & 32.22 & 0.14 \\
\hline Lao Cai & 0.01 & 0.01 & 0.56 & 0.10 & 0.39 & 0.01 & 12.35 & 0.46 & 0.01 & $19,307,282$ & 52.24 & 0.23 \\
\hline Yen Bai & 0.00 & 0.00 & 0.30 & 0.06 & 0.27 & 0.01 & 28.29 & 0.50 & 0.01 & $10,365,716$ & 29.71 & 0.21 \\
\hline $\begin{array}{c}\text { Thai } \\
\text { Nguyen }\end{array}$ & 0.01 & 0.02 & 0.38 & 0.13 & 0.56 & 0.01 & 7.81 & 0.32 & 0.01 & $50,008,720$ & 68.09 & 0.35 \\
\hline Lang Son & 0.00 & 0.00 & 0.28 & 0.06 & 0.19 & 0.01 & 23.89 & 0.56 & 0.01 & $10,569,443$ & 35.59 & 0.20 \\
\hline Bac Giang & 0.01 & 0.01 & 0.45 & 0.13 & 0.48 & 0.01 & 16.75 & 0.31 & 0.02 & $35,138,403$ & 42.05 & 0.11 \\
\hline Phu Tho & 0.01 & 0.01 & 0.46 & 0.08 & 0.39 & 0.01 & 30.01 & 0.39 & 0.02 & $23,656,951$ & 35.06 & 0.19 \\
\hline Dien Bien & 0.00 & 0.00 & 0.20 & 0.07 & 0.23 & 0.01 & 21.33 & 0.56 & 0.01 & $8,172,864$ & 24.15 & 0.15 \\
\hline
\end{tabular}




\begin{tabular}{|c|c|c|c|c|c|c|c|c|c|c|c|c|}
\hline Lai Chau & 0.00 & 0.00 & 0.27 & 0.12 & 0.49 & 0.01 & 15.02 & 0.35 & 0.01 & $3,946,049$ & 30.66 & 0.17 \\
\hline Son La & 0.00 & 0.01 & 0.14 & 0.10 & 0.35 & 0.00 & 7.36 & 0.42 & 0.02 & $14,825,440$ & 34.49 & 0.14 \\
\hline Hoa Binh & 0.00 & 0.01 & 0.17 & 0.09 & 0.45 & 0.00 & 7.54 & 0.32 & 0.01 & $10,677,100$ & 44.58 & 0.15 \\
\hline Thanh Hoa & 0.06 & 0.02 & 0.99 & 0.09 & 0.44 & 0.03 & 57.14 & 0.41 & 0.04 & $105,175,585$ & 37.64 & 0.17 \\
\hline Nghe An & 0.01 & 0.02 & 0.24 & 0.08 & 0.30 & 0.01 & 14.90 & 0.47 & 0.03 & $55,381,000$ & 34.14 & 0.15 \\
\hline Ha Tinh & 0.01 & 0.01 & 0.26 & 0.11 & 0.38 & 0.01 & 13.46 & 0.43 & 0.02 & $30,343,995$ & 39.63 & 0.18 \\
\hline $\begin{array}{l}\text { Quang } \\
\text { Binh }\end{array}$ & 0.01 & 0.01 & 0.46 & 0.07 & 0.24 & 0.01 & 37.16 & 0.57 & 0.02 & $16,532,400$ & 34.60 & 0.20 \\
\hline Quang Tri & 0.00 & 0.00 & 0.29 & 0.07 & 0.26 & 0.01 & 25.96 & 0.52 & 0.01 & $12,067,441$ & 39.25 & 0.30 \\
\hline $\begin{array}{c}\text { Thua } \\
\text { Thien-Hue }\end{array}$ & 0.01 & 0.01 & 0.31 & 0.08 & 0.34 & 0.01 & 19.53 & 0.54 & 0.01 & $18,849,760$ & 36.67 & 0.49 \\
\hline Da Nang & 0.02 & 0.01 & 1.01 & 0.07 & 0.34 & 0.02 & 23.15 & 0.64 & 0.02 & $36,042,929$ & 72.02 & 0.88 \\
\hline $\begin{array}{l}\text { Quang } \\
\text { Nam }\end{array}$ & 0.01 & 0.01 & 0.30 & 0.05 & 0.44 & 0.01 & 12.16 & 0.42 & 0.03 & $24,055,527$ & 55.86 & 0.24 \\
\hline $\begin{array}{l}\text { Quang } \\
\text { Ngai }\end{array}$ & 0.01 & 0.01 & 0.23 & 0.01 & 0.50 & 0.00 & 5.29 & 0.31 & 0.02 & $21,600,359$ & 50.84 & 0.15 \\
\hline Binh Dinh & 0.01 & 0.01 & 0.37 & 0.07 & 0.33 & 0.01 & 15.13 & 0.40 & 0.01 & $31,481,000$ & 41.27 & 0.31 \\
\hline Phu Yen & 0.00 & 0.01 & 0.19 & 0.07 & 0.30 & 0.01 & 6.06 & 0.45 & 0.01 & $13,116,400$ & 35.94 & 0.29 \\
\hline $\begin{array}{c}\text { Khanh } \\
\text { Hoa }\end{array}$ & 0.01 & 0.01 & 0.44 & 0.08 & 0.33 & 0.01 & 11.97 & 0.55 & 0.01 & $36,748,000$ & 57.07 & 0.45 \\
\hline $\begin{array}{l}\text { Ninh } \\
\text { Thuan }\end{array}$ & 0.00 & 0.00 & 0.35 & 0.09 & 0.21 & 0.01 & 31.60 & 0.40 & 0.01 & $6,777,700$ & 33.07 & 0.36 \\
\hline $\begin{array}{l}\text { Binh } \\
\text { Thuan }\end{array}$ & 0.00 & 0.01 & 0.16 & 0.07 & 0.30 & 0.00 & 9.98 & 0.38 & 0.01 & $20,026,152$ & 44.95 & 0.39 \\
\hline Kon Tum & 0.00 & 0.00 & 0.23 & 0.08 & 0.27 & 0.01 & 20.29 & 0.42 & 0.01 & $10,210,013$ & 34.24 & 0.36 \\
\hline Gia Lai & 0.00 & 0.01 & 0.13 & 0.08 & 0.23 & 0.00 & 4.61 & 0.45 & 0.01 & $18,952,056$ & 38.59 & 0.30 \\
\hline Dak Lak & 0.00 & 0.01 & 0.15 & 0.07 & 0.14 & 0.00 & 14.46 & 0.45 & 0.02 & $22,777,564$ & 34.64 & 0.24 \\
\hline Dak Nong & 0.00 & 0.00 & 0.10 & 0.08 & 0.17 & 0.00 & 6.06 & 0.38 & 0.01 & $9,697,057$ & 39.71 & 0.15 \\
\hline Lam Dong & 0.00 & 0.01 & 0.18 & 0.08 & 0.17 & 0.00 & 4.88 & 0.35 & 0.01 & $23,500,000$ & 54.86 & 0.39 \\
\hline $\begin{array}{l}\text { Binh } \\
\text { Phuoc }\end{array}$ & 0.01 & 0.01 & 0.44 & 0.07 & 0.37 & 0.01 & 15.66 & 0.36 & 0.01 & $18,433,920$ & 53.06 & 0.20 \\
\hline Tay Ninh & 0.01 & 0.01 & 0.59 & 0.08 & 0.39 & 0.01 & 17.23 & 0.35 & 0.01 & $22,626,374$ & 56.87 & 0.22 \\
\hline $\begin{array}{c}\text { Binh } \\
\text { Duong }\end{array}$ & 0.06 & 0.04 & 1.55 & 0.09 & 0.70 & 0.01 & 16.80 & 0.26 & 0.02 & $81,284,638$ & $\begin{array}{c}119.7 \\
5\end{array}$ & 0.76 \\
\hline Dong Nai & 0.12 & 0.05 & 2.22 & 0.08 & 0.65 & 0.03 & 36.93 & 0.25 & 0.03 & $69,170,731$ & 92.37 & 0.35 \\
\hline $\begin{array}{c}\text { Ba Ria- } \\
\text { Vung Tau }\end{array}$ & 0.02 & 0.05 & 0.86 & -0.04 & 0.80 & 0.00 & 2.55 & 0.15 & 0.01 & $39,627,000$ & $\begin{array}{c}249.4 \\
9\end{array}$ & 0.52 \\
\hline $\begin{array}{l}\text { Ho Chi } \\
\text { Minh city }\end{array}$ & 0.12 & 0.17 & 0.81 & 0.08 & 0.30 & 0.01 & 13.02 & 0.70 & 0.05 & $365,710,000$ & $\begin{array}{c}122.7 \\
1\end{array}$ & 0.81 \\
\hline Long An & 0.02 & 0.02 & 0.83 & 0.10 & 0.47 & 0.01 & 24.57 & 0.34 & 0.02 & $26,237,219$ & 61.26 & 0.18 \\
\hline $\begin{array}{l}\text { Tien } \\
\text { Giang }\end{array}$ & 0.01 & 0.01 & 0.46 & 0.08 & 0.30 & 0.01 & 29.33 & 0.30 & 0.01 & $29,138,940$ & 43.65 & 0.16 \\
\hline Ben Tre & 0.01 & 0.01 & 0.31 & 0.07 & 0.17 & 0.01 & 35.22 & 0.47 & 0.01 & $15,293,000$ & 31.08 & 0.11 \\
\hline Tra Vinh & 0.00 & 0.01 & 0.20 & 0.12 & 0.32 & 0.01 & 14.18 & 0.32 & 0.01 & $20,697,998$ & 39.22 & 0.18 \\
\hline Vinh Long & 0.00 & 0.01 & 0.15 & 0.06 & 0.18 & 0.00 & 16.94 & 0.47 & 0.01 & $12,604,154$ & 41.28 & 0.17 \\
\hline $\begin{array}{l}\text { Dong } \\
\text { Thap }\end{array}$ & 0.01 & 0.01 & 0.26 & 0.06 & 0.24 & 0.01 & 28.51 & 0.39 & 0.01 & $16,670,744$ & 36.28 & 0.18 \\
\hline An Giang & 0.01 & 0.01 & 0.18 & 0.05 & 0.15 & 0.01 & 23.35 & 0.55 & 0.02 & $12,372,899$ & 33.98 & 0.31 \\
\hline $\begin{array}{l}\text { Kien } \\
\text { Giang }\end{array}$ & 0.02 & 0.01 & 0.53 & 0.07 & 0.20 & 0.01 & 14.73 & 0.43 & 0.02 & $43,527,058$ & 43.12 & 0.29 \\
\hline
\end{tabular}




\begin{tabular}{ccccccccccccc}
\hline Can Tho & 0.01 & 0.01 & 0.40 & 0.07 & 0.34 & 0.01 & 16.63 & 0.56 & 0.01 & $54,888,604$ & 61.51 & 0.67 \\
\hline Hau Giang & 0.00 & 0.00 & 0.10 & 0.07 & 0.22 & 0.00 & 7.90 & 0.48 & 0.01 & $16,680,500$ & 33.60 & 0.26 \\
\hline Soc Trang & 0.00 & 0.01 & 0.11 & 0.04 & 0.17 & 0.00 & 12.26 & 0.42 & 0.01 & $9,774,546$ & 33.62 & 0.31 \\
\hline Bac Lieu & 0.00 & 0.01 & 0.17 & 0.07 & 0.15 & 0.00 & 19.85 & 0.42 & 0.00 & $14,203,860$ & 37.50 & 0.29 \\
\hline Ca Mau & 0.00 & 0.01 & 0.15 & 0.04 & 0.29 & 0.00 & 10.63 & 0.43 & 0.01 & $11,361,073$ & 38.00 & 0.23
\end{tabular}

The dendrogram obtained by using the Ward's method for the lustering of the 63 provinces shows in Figure 4. It indicates that provinces can be grouped into 7 clusters. The detail provinces included in each cluster is shown in Table 3. The centroids of the 7 clusters will be used as initial condition for the K-means method, where the same result is still obtained (see Table 4), confirming that the result from Ward's method is reasonable.

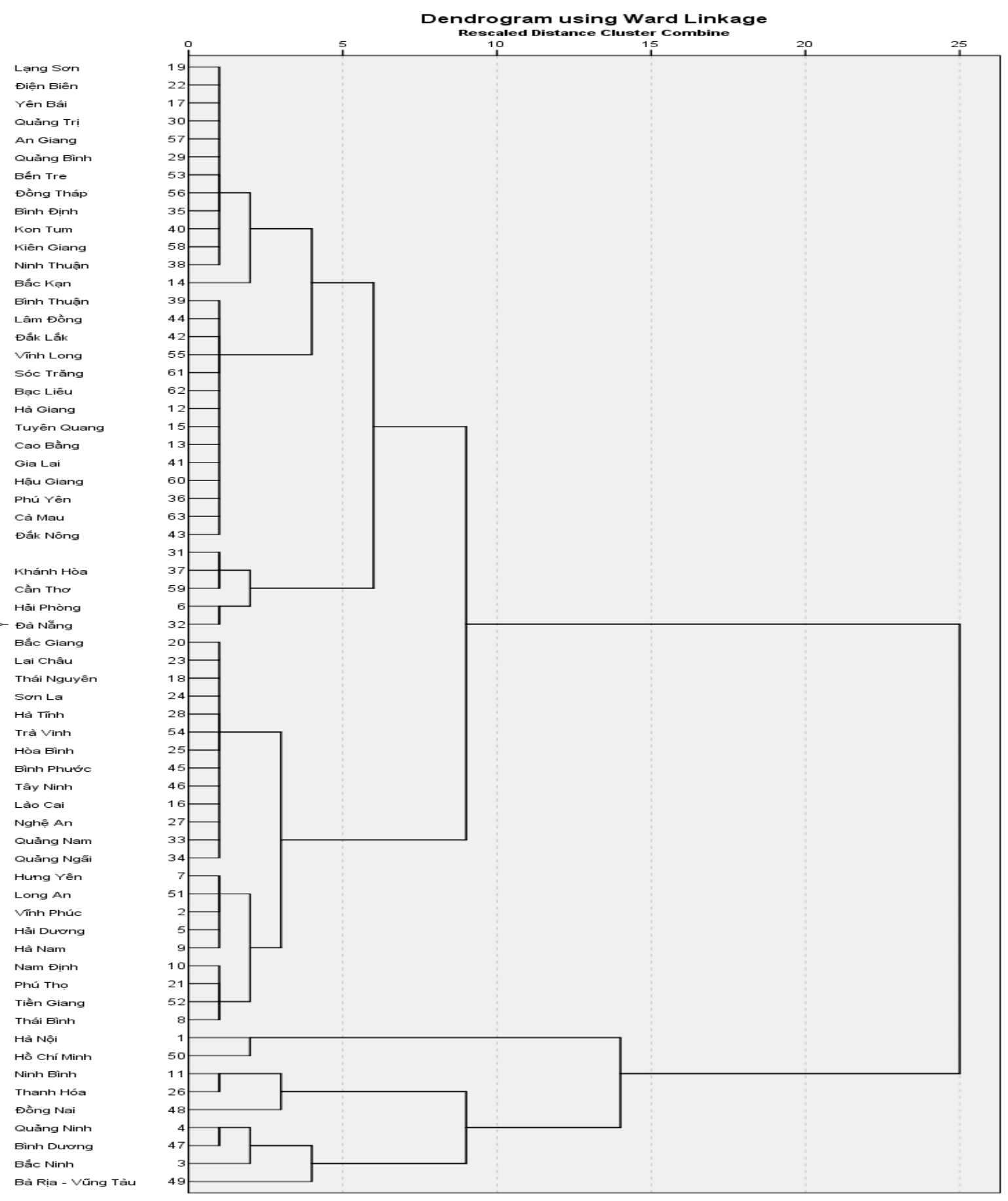

Figure 4. Dendrogram from the Ward's method 
Table 3. Results of the cluster analysis

\begin{tabular}{|c|c|c|}
\hline Cluster & $\begin{array}{l}\text { Number of } \\
\text { provinces }\end{array}$ & Province included \\
\hline 1 & 2 & Ha Noi, Ho Chi Minh city. \\
\hline 2 & 3 & Ninh Binh, Thanh Hoa, Dong Nai. \\
\hline 3 & 4 & Quang Ninh, Binh Duong, Bac Ninh, Ba Ria-Vung Tau. \\
\hline 4 & 9 & $\begin{array}{c}\text { Hung Yen, Long An, Vinh Phuc, Hai Duong, Ha Nam, Nam Dinh, Phu } \\
\text { Tho, Tien Giang, Thai Binh. }\end{array}$ \\
\hline 5 & 13 & $\begin{array}{c}\text { Bac Giang, Lai Chau, Thai Nguyen, Son La, Ha Tinh, Tra Vinh, Hoa } \\
\text { Binh, Binh Phuoc, Tay Ninh, Lao Cai, Nghe An, Quang Nam, Quang } \\
\text { Ngai. }\end{array}$ \\
\hline 6 & 5 & Binh Thuan, Khanh Hoa, Can Tho, Hai Phong, Da Nang. \\
\hline 7 & 27 & $\begin{array}{c}\text { Lang Son, Dien Bien, Yen Bai, Quang Tri, An Giang, Quang Binh, Ben } \\
\text { Tre, Dong Thap, Kon Tum, Kien Giang, Ninh Thuan, Bac Kan, Binh } \\
\text { Thuan, Lam Dong, Dak Lak, Vinh Long, Soc Trang, Bac Lieu, Ha } \\
\text { Giang, Tuyen Quang, Cao Bang, Gia Lai, Hau Giang, Phu Yen, Ca } \\
\text { Mau, Dak Nong, Bình Định. }\end{array}$ \\
\hline
\end{tabular}

Table 4. Mean values of indicator at the cluster centroids

\begin{tabular}{|c|c|c|c|c|c|c|c|}
\hline \multirow{2}{*}{ Indicator } & \multicolumn{7}{|c|}{ Cluster } \\
\hline & 1 & 2 & 3 & 4 & 5 & 6 & 7 \\
\hline $\begin{array}{l}\text { The proportion of } \\
\text { energy consumption }\end{array}$ & 0.12 & 0.12 & 0.04 & 0.02 & 0.01 & 0.07 & 0.00 \\
\hline $\begin{array}{c}\text { The proportion of } \\
\text { GDP }\end{array}$ & 0.11 & 0.17 & 0.03 & 0.02 & 0.01 & 0.04 & 0.01 \\
\hline $\begin{array}{l}\text { Per capita energy } \\
\text { consumption }\end{array}$ & 0.87 & 0.81 & 1.07 & 0.61 & 0.48 & 1.72 & 0.22 \\
\hline $\begin{array}{l}\text { Regional GDP } \\
\text { growth rate }\end{array}$ & 0.09 & 0.08 & 0.14 & 0.07 & 0.08 & 0.10 & 0.07 \\
\hline $\begin{array}{c}\text { The proportion of } \\
\text { industrial added } \\
\text { value to GDP }\end{array}$ & 0.33 & 0.30 & 0.59 & 0.45 & 0.39 & 0.59 & 0.25 \\
\hline $\begin{array}{c}\text { Energy consumption } \\
\text { per GDP (TOE/VND } \\
\text { mil) }\end{array}$ & 0.01 & 0.01 & 0.02 & 0.01 & 0.01 & 0.02 & 0.01 \\
\hline $\begin{array}{l}\text { Energy consumption } \\
\text { per unit of Industry } \\
\text { Value added GDP } \\
\text { (TOE/VND mil) }\end{array}$ & 18.46 & 13.02 & 33.02 & 15.50 & 17.89 & 23.43 & 20.41 \\
\hline $\begin{array}{l}\text { The third industry } \\
\text { proportion of GDP }\end{array}$ & 0.64 & 0.70 & 0.32 & 0.38 & 0.40 & 0.34 & 0.46 \\
\hline $\begin{array}{l}\text { The proportion of } \\
\text { financial } \\
\text { expenditure in the } \\
\text { whole country }\end{array}$ & 0.10 & 0.05 & 0.03 & 0.02 & 0.01 & 0.02 & 0.01 \\
\hline $\begin{array}{l}\text { Investment in fixed } \\
\text { assets (VND bil.) }\end{array}$ & $308,219,000$ & $365,710,000$ & $112,216,293$ & $50,762,601$ & $26,438,572$ & $74,109,905$ & $11,201,543$ \\
\hline $\begin{array}{c}\text { Per capita GDP } \\
\text { (VND mil/capita) }\end{array}$ & 85.97 & 122.71 & 85.48 & 85.23 & 48.19 & 98.37 & 34.45 \\
\hline Urbanization rate & 0.49 & 0.81 & 0.22 & 0.39 & 0.27 & 0.53 & 0.22 \\
\hline
\end{tabular}


Clusters 1 is region with a developed economy but with low reduction potential. Cluster 1 includes two municipalities, i.e., Ha Noi and Ho Chi Minh city, and represents the most advanced level of economy, with its per capita GDP over VND 90 mil. and the highest sharing of the total energy consumption (24\%) as well as of GDP $(28 \%)$ those are much higher than the other 6 clusters. This high level of living standard also leads to high per capita energy consumption. However, its economic structure and energy efficiency are relatively optimal, indicating a low reduction potential. Cluster 2 includes 3 provinces, which are featured by large scale industry and high total energy consumption which shares $20 \%$ of the national energy consumption whistle contributed $8.0 \%$ share of GDP. The cluster 3 seems to be energy efficiency likely as the cluster 1 because of the GDP share contribution is higher than the energy consumption share. It also takes note that the number of provinces in this cluster is two times higher than in the cluster 1 . Cluster 7 has numerous of provinces, taking almost $1 / 3$ number of the Vietnam's provinces (27/63), however, it is less contribution in the GDP although energy consumption takes about $11 \%$ of the national level. It is noticeable for cluster 6 , which included 5 provinces. A characteristic of these provinces is that the service sector takes high share in the economy. However, the cluster's energy consumption share is higher than its contribution on national GDP may attribute to problems in behavior's energy use. Table 5 shows the indicator values for all clusters.

Table 5. Indicator values for the clusters

\begin{tabular}{cccccccccc}
\hline Cluster & PEC & PGDP & PCEC & RGDPGR & PI & ECPGDP & ECPIGDP & $\begin{array}{c}\text { 3rdIPG } \\
\text { DP }\end{array}$ & PFE \\
\hline $\mathbf{1}$ & 0.24 & 0.28 & 1.68 & 0.17 & 0.62 & 0.02 & 31.48 & 1.33 & 0.15 \\
\hline $\mathbf{2}$ & 0.20 & 0.08 & 4.31 & 0.25 & 1.49 & 0.08 & 143.13 & 1.14 & 0.08 \\
\hline $\mathbf{3}$ & 0.12 & 0.14 & 4.75 & 0.34 & 2.81 & 0.04 & 38.86 & 0.99 & 0.07 \\
\hline $\mathbf{4}$ & 0.14 & 0.11 & 5.71 & 0.78 & 4.16 & 0.13 & 226.56 & 3.07 & 0.14 \\
\hline $\mathbf{5}$ & 0.09 & 0.13 & 4.23 & 1.18 & 5.44 & 0.10 & 159.71 & 4.82 & 0.19 \\
\hline $\mathbf{6}$ & 0.09 & 0.07 & 3.55 & 0.43 & 1.78 & 0.06 & 87.84 & 2.81 & 0.08 \\
\hline $\mathbf{7}$ & 0.11 & 0.19 & 6.04 & 1.84 & 5.92 & 0.18 & 528.51 & 12.44 & 0.29 \\
\hline
\end{tabular}

\subsection{National-level projection of energy consumption and energy saving.}

National-level projections of energy and intensity for the first stage of the VNEEP are based on three main assumptions: (1) a national energy saving improvement target of $7 \%$ over the period of 2019 - 20125; (2) annual GDP growth of 7.6\%; and (3) a little shift in energy structure, from 41\% industrial, $25 \%$ residential, $34 \%$ other energy (service, transportation, etc..); to $37 \%, 27 \%$ and $26 \%$, respectively. Using these assumptions, energy and GDP are projected out to 2025. Figure 5 shows the results of the national-level projections of energy consumption, saving and energy intensity. 


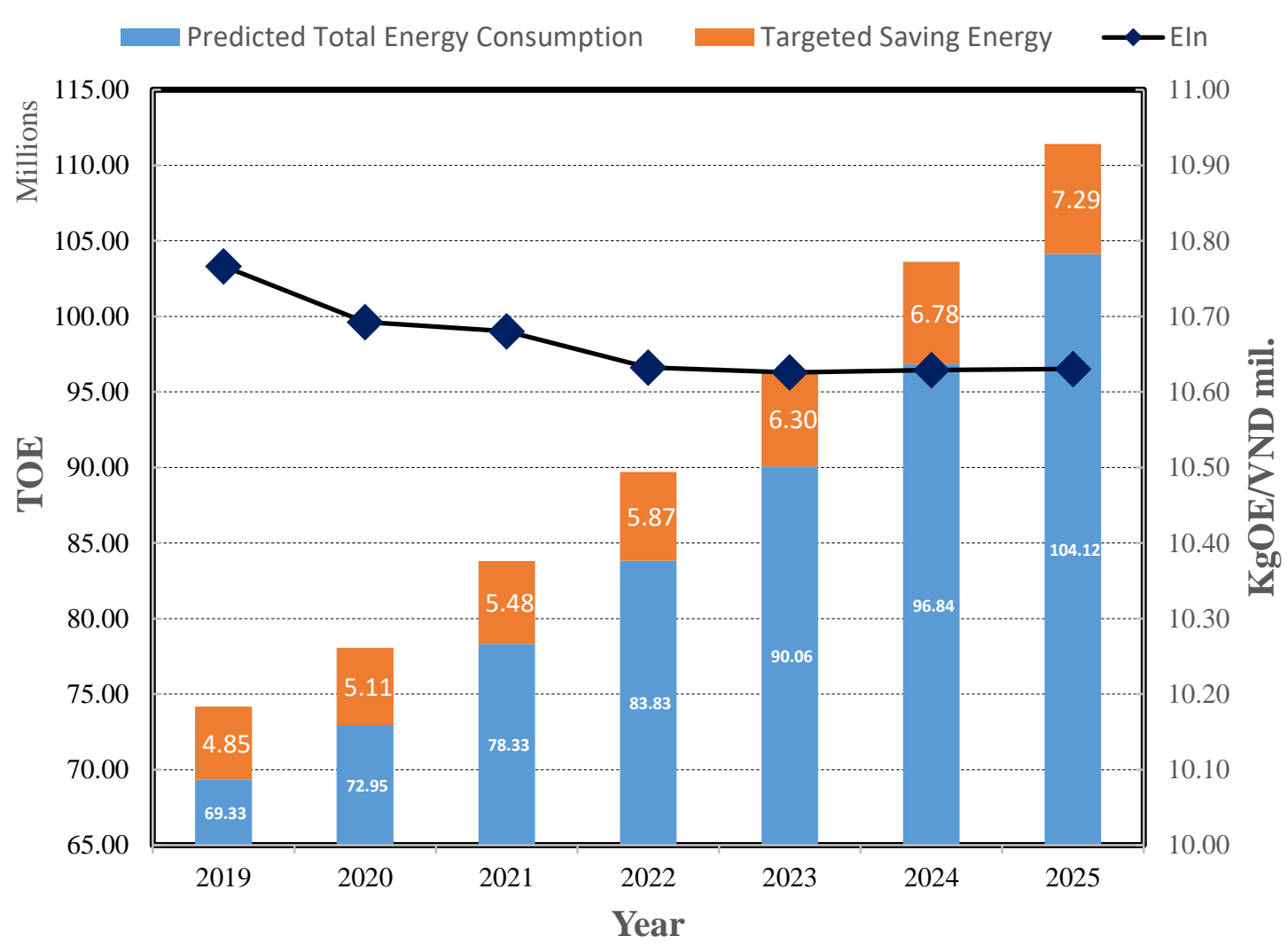

Figure 5. National-level Projection of energy consumption, saving and energy intensity

In national level, the energy consumption increases yearly and will reach about 104 mil. TOE. Assignment of $7 \%$ energy saving, the total energy saving in the period is about $41.67 \mathrm{mil}$. TOE. The energy intensity will decrease yearly from 2019 to 2023 and be level-off in the remaining year. In general, the improvement of the energy intensity will be not much due to small lifting the economy structure.

\subsection{Allocation of energy efficiency target for the provinces}

Under the national socio-economic development defined in the national-level projection in cooperation with historical trend of each province, the regional energy consumption and the socioeconomic development is projection. Table 6 shows the predicted amount of the final energy consumption for each province. The predicted results confirm the consistency to the province clustering. Provinces included in the cluster 1,2 and 3 are main players in the future energy consumption of Vietnam. As shown in Table 6, the energy consumption for each province increases yearly in the period. All provinces, the energy consumption in 2015 will be double in comparison in 2019. It means that the regional economic development still bases the intensive energy consumption.

Table 6. The predicted energy consumption for each province in the period of 2019 - 2025 (in TOE)

\begin{tabular}{cccccccc}
\hline & $\mathbf{2 0 1 9}$ & $\mathbf{2 0 2 0}$ & $\mathbf{2 0 2 1}$ & $\mathbf{2 0 2 2}$ & $\mathbf{2 0 2 3}$ & $\mathbf{2 0 2 4}$ & $\mathbf{2 0 2 5}$ \\
\hline $\begin{array}{c}\text { Ha } \\
\text { Noi }\end{array}$ & $9,017,766$ & $10,042,358$ & $11,183,365$ & $12,454,012$ & $13,869,028$ & $15,444,819$ & $17,199,649$ \\
\hline $\begin{array}{c}\text { Vinh } \\
\text { Phuc }\end{array}$ & $1,190,791$ & $1,305,978$ & $1,432,307$ & $1,570,856$ & $1,722,808$ & $1,889,458$ & $2,072,228$ \\
\hline $\begin{array}{r}\text { Bac } \\
\text { Ninh }\end{array}$ & 670,599 & 812,131 & 983,535 & $1,191,113$ & $1,442,503$ & $1,746,949$ & $2,115,649$ \\
\hline
\end{tabular}




\begin{tabular}{|c|c|c|c|c|c|c|c|}
\hline $\begin{array}{l}\text { Quang } \\
\text { Ninh }\end{array}$ & $12,209,577$ & $14,004,249$ & $16,062,718$ & $18,423,760$ & $21,131,848$ & $24,237,996$ & $27,800,713$ \\
\hline $\begin{array}{c}\text { Hai } \\
\text { Duong }\end{array}$ & $3,115,964$ & $3,482,698$ & $3,892,595$ & $4,350,735$ & $4,862,795$ & $5,435,122$ & $6,074,810$ \\
\hline $\begin{array}{c}\text { Hai } \\
\text { Phong }\end{array}$ & $5,617,010$ & $6,544,701$ & $7,625,607$ & $8,885,032$ & $10,352,461$ & $12,062,247$ & $14,054,417$ \\
\hline $\begin{array}{c}\text { Hung } \\
\text { Yen }\end{array}$ & 849,051 & 950,713 & $1,064,546$ & $1,192,010$ & $1,334,736$ & $1,494,551$ & $1,673,501$ \\
\hline $\begin{array}{l}\text { Thai } \\
\text { Binh }\end{array}$ & 502,116 & 566,303 & 638,694 & 720,340 & 812,423 & 916,277 & $1,033,407$ \\
\hline $\begin{array}{c}\mathrm{Ha} \\
\text { Nam }\end{array}$ & $1,156,384$ & $1,335,866$ & 1,543,207 & $1,782,729$ & $2,059,427$ & $2,379,072$ & $2,748,329$ \\
\hline $\begin{array}{l}\text { Nam } \\
\text { Dinh }\end{array}$ & 340,916 & 376,139 & 415,000 & 457,876 & 505,182 & 557,376 & 614,962 \\
\hline $\begin{array}{l}\text { Ninh } \\
\text { Binh }\end{array}$ & $2,927,064$ & $3,282,853$ & $3,681,888$ & $4,129,426$ & $4,631,363$ & $5,194,311$ & $5,825,687$ \\
\hline $\begin{array}{c}\text { Ha } \\
\text { Giang }\end{array}$ & 47,165 & 53,468 & 60,614 & 68,714 & 77,896 & 88,306 & 100,107 \\
\hline $\begin{array}{c}\text { Cao } \\
\text { Bang }\end{array}$ & 155,522 & 171,991 & 190,203 & 210,344 & 232,618 & 257,250 & 284,491 \\
\hline $\begin{array}{l}\text { Bac } \\
\text { Kan }\end{array}$ & 63,552 & 71,144 & 79,644 & 89,159 & 99,811 & 111,736 & 125,085 \\
\hline $\begin{array}{l}\text { Tuyen } \\
\text { Quang }\end{array}$ & 778,963 & 884,415 & $1,004,144$ & $1,140,080$ & $1,294,419$ & $1,469,651$ & $1,668,606$ \\
\hline $\begin{array}{l}\text { Lao } \\
\text { Cai }\end{array}$ & 302,364 & 353,322 & 412,869 & 482,451 & 563,760 & 658,772 & 769,797 \\
\hline $\begin{array}{l}\text { Yen } \\
\text { Bai }\end{array}$ & 898,748 & $1,004,227$ & $1,122,086$ & $1,253,777$ & $1,400,923$ & $1,565,338$ & $1,749,050$ \\
\hline $\begin{array}{c}\text { Thai } \\
\text { Nguye } \\
\text { n }\end{array}$ & 1,891,718 & 2,276,209 & $2,738,847$ & $3,295,516$ & $3,965,328$ & $4,771,279$ & $5,741,039$ \\
\hline $\begin{array}{c}\text { Lang } \\
\text { Son }\end{array}$ & 619,681 & 693,217 & 775,479 & 867,504 & 970,448 & $1,085,609$ & $1,214,436$ \\
\hline $\begin{array}{c}\text { Bac } \\
\text { Giang }\end{array}$ & $2,755,421$ & $3,260,703$ & $3,858,642$ & $4,566,230$ & $5,403,574$ & $6,394,468$ & $7,567,069$ \\
\hline $\begin{array}{l}\text { Phu } \\
\text { Tho }\end{array}$ & 902,888 & $1,013,270$ & $1,137,148$ & $1,276,171$ & $1,432,190$ & $1,607,283$ & $1,803,781$ \\
\hline $\begin{array}{l}\text { Dien } \\
\text { Bien }\end{array}$ & 115,410 & 128,964 & 144,110 & 161,035 & 179,947 & 201,081 & 224,697 \\
\hline $\begin{array}{c}\text { Lai } \\
\text { Chau }\end{array}$ & 49,809 & 60,190 & 72,735 & 87,895 & 106,215 & 128,352 & 155,104 \\
\hline Son La & 190,824 & 226,716 & 269,359 & 320,022 & 380,215 & 451,729 & 536,695 \\
\hline $\begin{array}{c}\text { Hoa } \\
\text { Binh }\end{array}$ & 205,644 & 235,150 & 268,889 & 307,469 & 351,584 & 402,029 & 459,712 \\
\hline $\begin{array}{c}\text { Thanh } \\
\text { Hoa }\end{array}$ & $3,478,599$ & $4,003,904$ & 4,608,535 & $5,304,472$ & $6,105,503$ & $7,027,498$ & $8,088,724$ \\
\hline $\begin{array}{c}\text { Nghe } \\
\text { An }\end{array}$ & 909,522 & $1,040,597$ & $1,190,561$ & $1,362,138$ & $1,558,440$ & $1,783,033$ & $2,039,993$ \\
\hline $\begin{array}{c}\text { Ha } \\
\text { Tinh }\end{array}$ & $2,559,503$ & $3,043,808$ & $3,619,752$ & $4,304,674$ & $5,119,196$ & $6,087,841$ & $7,239,771$ \\
\hline $\begin{array}{c}\text { Quang } \\
\text { Binh }\end{array}$ & 687,728 & 773,173 & 869,233 & 977,228 & $1,098,640$ & $1,235,137$ & $1,388,593$ \\
\hline
\end{tabular}




\begin{tabular}{|c|c|c|c|c|c|c|c|}
\hline $\begin{array}{c}\text { Quang } \\
\text { Tri }\end{array}$ & 94,908 & 108,411 & 123,835 & 141,454 & 161,579 & 184,567 & 210,826 \\
\hline Thua & & & & & & & \\
\hline $\begin{array}{c}\text { Thien- } \\
\text { Hue }\end{array}$ & 416,696 & 469,986 & 530,091 & 597,882 & 674,343 & 760,583 & 857,851 \\
\hline $\begin{array}{c}\text { Da } \\
\text { Nang }\end{array}$ & 651,707 & 736,685 & 832,745 & 941,330 & $1,064,074$ & $1,202,822$ & $1,359,663$ \\
\hline $\begin{array}{l}\text { Quang } \\
\text { Nam }\end{array}$ & 660,156 & 770,883 & 900,181 & $1,051,167$ & $1,227,478$ & $1,433,360$ & $1,673,775$ \\
\hline $\begin{array}{l}\text { Quang } \\
\text { Ngai }\end{array}$ & $3,315,835$ & $3,727,322$ & $4,189,874$ & $4,709,827$ & $5,294,305$ & $5,951,315$ & $6,689,859$ \\
\hline $\begin{array}{l}\text { Binh } \\
\text { Dinh }\end{array}$ & 559,803 & 626,898 & 702,034 & 786,175 & 880,401 & 985,921 & $1,104,087$ \\
\hline $\begin{array}{l}\text { Phu } \\
\text { Yen }\end{array}$ & 75,886 & 85,915 & 97,270 & 110,125 & 124,680 & 141,157 & 159,813 \\
\hline $\begin{array}{c}\text { Khanh } \\
\text { Hoa }\end{array}$ & 332,571 & 375,871 & 424,810 & 480,119 & 542,630 & 613,281 & 693,129 \\
\hline $\begin{array}{l}\text { Ninh } \\
\text { Thuan }\end{array}$ & 613,363 & 695,618 & 788,903 & 894,698 & $1,014,681$ & $1,150,753$ & $1,305,074$ \\
\hline $\begin{array}{c}\text { Binh } \\
\text { Thuan }\end{array}$ & 492,199 & 558,226 & 633,109 & 718,038 & 814,360 & 923,604 & $1,047,501$ \\
\hline $\begin{array}{l}\text { Kon } \\
\text { Tum }\end{array}$ & 71,206 & 81,557 & 93,413 & 106,992 & 122,545 & 140,359 & 160,762 \\
\hline $\begin{array}{l}\text { Gia } \\
\text { Lai }\end{array}$ & 810,375 & 931,652 & $1,071,079$ & $1,231,372$ & $1,415,654$ & $1,627,515$ & $1,871,082$ \\
\hline $\begin{array}{c}\text { Dak } \\
\text { Lak }\end{array}$ & 416,740 & 466,538 & 522,287 & 584,697 & 654,565 & 732,781 & 820,344 \\
\hline $\begin{array}{c}\text { Dak } \\
\text { Nong }\end{array}$ & 115,157 & 136,149 & 160,968 & 190,312 & 225,005 & 266,022 & 314,517 \\
\hline $\begin{array}{c}\text { Lam } \\
\text { Dong }\end{array}$ & 583,821 & 671,884 & 773,231 & 889,866 & $1,024,093$ & $1,178,567$ & $1,356,342$ \\
\hline $\begin{array}{l}\text { Binh } \\
\text { Phuoc }\end{array}$ & 784,451 & 901,571 & $1,036,177$ & $1,190,881$ & $1,368,681$ & $1,573,028$ & $1,807,884$ \\
\hline $\begin{array}{c}\text { Tay } \\
\text { Ninh }\end{array}$ & 357,055 & 405,017 & 459,422 & 521,135 & 591,137 & 670,543 & 760,615 \\
\hline $\begin{array}{c}\text { Binh } \\
\text { Duong }\end{array}$ & $2,004,434$ & $2,282,318$ & $2,598,725$ & $2,958,998$ & $3,369,216$ & $3,836,305$ & $4,368,148$ \\
\hline $\begin{array}{c}\text { Dong } \\
\text { Nai }\end{array}$ & $3,916,494$ & $4,407,172$ & $4,959,325$ & $5,580,654$ & $6,279,826$ & $7,066,594$ & $7,951,933$ \\
\hline $\begin{array}{c}\text { Ba } \\
\text { Ria- } \\
\text { Vung } \\
\text { Tau }\end{array}$ & $1,616,462$ & $1,684,554$ & $1,755,514$ & $1,829,464$ & $1,906,528$ & $1,986,839$ & $2,070,533$ \\
\hline $\begin{array}{c}\text { Ho } \\
\text { Chi } \\
\text { Minh } \\
\text { city }\end{array}$ & $6,144,729$ & $6,923,308$ & $7,800,538$ & $8,788,919$ & $9,902,534$ & $11,157,252$ & $12,570,951$ \\
\hline $\begin{array}{c}\text { Long } \\
\text { An }\end{array}$ & 383,633 & 444,156 & 514,227 & 595,354 & 689,279 & 798,022 & 923,920 \\
\hline $\begin{array}{c}\text { Tien } \\
\text { Giang }\end{array}$ & 603,448 & 681,552 & 769,766 & 869,397 & 981,923 & $1,109,014$ & $1,252,554$ \\
\hline
\end{tabular}




\begin{tabular}{cccccccc}
\hline $\begin{array}{c}\text { Ben } \\
\text { Tre }\end{array}$ & 193,391 & 214,288 & 237,444 & 263,101 & 291,531 & 323,034 & 357,940 \\
\hline $\begin{array}{c}\text { Tra } \\
\text { Vinh }\end{array}$ & $3,349,935$ & $3,867,035$ & $4,463,956$ & $5,153,019$ & $5,948,446$ & $6,866,656$ & $7,926,603$ \\
\hline $\begin{array}{c}\text { Vinh } \\
\text { Long }\end{array}$ & 88,270 & 97,823 & 108,411 & 120,145 & 133,150 & 147,561 & 163,533 \\
\hline $\begin{array}{c}\text { Dong } \\
\text { Thap }\end{array}$ & 112,213 & 124,388 & 137,883 & 152,843 & 169,425 & 187,807 & 208,183 \\
\hline $\begin{array}{c}\text { An } \\
\text { Giang }\end{array}$ & 145,961 & 160,145 & 175,707 & 192,781 & 211,514 & 232,068 & 254,619 \\
\hline $\begin{array}{c}\text { Kien } \\
\text { Giang }\end{array}$ & 959,997 & $1,059,947$ & $1,170,303$ & $1,292,150$ & $1,426,682$ & $1,575,221$ & $1,739,225$ \\
\hline $\begin{array}{c}\text { Can } \\
\text { Tho }\end{array}$ & 144,715 & 159,318 & 175,395 & 193,094 & 212,578 & 234,029 & 257,645 \\
\hline $\begin{array}{c}\text { Hau } \\
\text { Giang }\end{array}$ & 24,956 & 27,699 & 30,743 & 34,122 & 37,873 & 42,035 & 46,655 \\
\hline $\begin{array}{c}\text { Soc } \\
\text { Trang }\end{array}$ & 40,189 & 44,294 & 48,819 & 53,806 & 59,302 & 65,359 & 72,035 \\
\hline $\begin{array}{c}\text { Bac } \\
\text { Lieu }\end{array}$ & 102,300 & 113,163 & 125,180 & 138,472 & 153,176 & 169,441 & 187,433 \\
\hline $\begin{array}{c}\text { Ca } \\
\text { Mau }\end{array}$ & 93,017 & 102,088 & 112,044 & 122,971 & 134,964 & 148,126 & 162,572 \\
\hline
\end{tabular}

The VNEEP has set the goal of the national level target is $7 \%$ saving of total energy consumption in the period of $2019-2025$, the 63 provinces are main actors to implementation of the national target. Therefore, allocation of the national target to the provincial target ensures that sum of the province saving energy amount has to meet the national energy saving amount. The allocation mechanism has to be based on the provincial characteristic of energy efficiency such as responsibility, ability, potential, difficulty.

Using MATLAB genetic algorithm programming, the amount of saving energy of each province was iteratively calculated and re-examined to meet the national goal. Detail calculation results are shown in Table 7.

Table 7. Result of target allocation

\begin{tabular}{|c|c|c|c|}
\hline Cluster & $\begin{array}{l}\text { Number of } \\
\text { provinces }\end{array}$ & Province included & $\begin{array}{l}\text { Allocated target } \\
\text { in } \%\end{array}$ \\
\hline 1 & 2 & Ha Noi, Ho Chi Minh city. & 7.25 \\
\hline 2 & 3 & Ninh Binh, Thanh Hoa, Dong Nai. & 7.90 \\
\hline 3 & 4 & $\begin{array}{c}\text { Quang Ninh, Binh Duong, Bac Ninh, Ba Ria- } \\
\text { Vung Tau. }\end{array}$ & 7.65 \\
\hline 4 & 9 & $\begin{array}{l}\text { Hung Yen, Long An, Vinh Phuc, Hai Duong, } \\
\text { Ha Nam, Nam Dinh, Phu Tho, Tien Giang, } \\
\text { Thai Binh. }\end{array}$ & 7.25 \\
\hline 5 & 13 & $\begin{array}{c}\text { Bac Giang, Lai Chau, Thai Nguyen, Son La, Ha } \\
\text { Tinh, Tra Vinh, Hoa Binh, Binh Phuoc, Tay } \\
\text { Ninh, Lao Cai, Nghe An, Quang Nam, Quang } \\
\text { Ngai. }\end{array}$ & 6.75 \\
\hline 6 & 5 & $\begin{array}{c}\text { Binh Thuan, Khanh Hoa, Can Tho, Hai Phong, } \\
\text { Da Nang. }\end{array}$ & 7.0 \\
\hline 7 & 27 & $\begin{array}{l}\text { Lang Son, Dien Bien, Yen Bai, Quang Tri, An } \\
\text { Giang, Quang Binh, Ben Tre, Dong Thap, Kon } \\
\text { Tum, Kien Giang, Ninh Thuan, Bac Kan, Binh } \\
\text { Thuan, Lam Dong, Dak Lak, Vinh Long, Soc }\end{array}$ & 4.75 \\
\hline
\end{tabular}




\section{Trang, Bac Lieu, Ha Giang, Tuyen Quang, Cao \\ Bang, Gia Lai, Hau Giang, Phu Yen, Ca Mau, \\ Dak Nong, Bình Định.}

As seen in Table 7, each cluster assigns different energy saving target. There are 28 provinces included in the cluster 1, 2, and 3 assigned higher rate of saving energy than the national rate. These provinces had high economic development level and high energy consumption. Among those cluster, the cluster 1 included Ha Noi and Ho Chi Minh city contributes highest share for national GDP assigned lower energy saving rate than the cluster 2 and 3. It is reasonable assignment because of their high percentage of energy consumption in service sector (logistic, transportation, commercial etc.). The cluster 2 and 3 assigned $7.90 \%$ and $7.65 \%$, respectively. The provinces include in these clusters had economic development based secondary industry. The provinces in the cluster 4 has restructured economy based on industrialization recently and will play important role in the future of Vietnam energy consumption. The cluster 5 included Hai Phong, Can Tho, Da Nang, and Binh Thuan province is allocated $7.0 \%$ equal to the national goal level because these provinces had economic development strongly focused on services. The cluster 4 and 7 are set $6.75 \%$ and $4.50 \%$ saving target, respectively. Specially, the cluster 7 included 27 provinces assigns only $4.75 \%$ energy saving rate. These provinces are lowest level of economy development with economy feature is only based on the primary industry. Table 8 shows the amount of saving energy for provinces consistency with the $7.00 \%$ national energy saving target in the period of $2019-2025$.

Table 8. Amount of saving energy for each province in the period of $2019-2025$ (in TOE)

\begin{tabular}{cccccccc}
\hline & $\mathbf{2 0 1 9}$ & $\mathbf{2 0 2 0}$ & $\mathbf{2 0 2 1}$ & $\mathbf{2 0 2 2}$ & $\mathbf{2 0 2 3}$ & $\mathbf{2 0 2 4}$ & $\mathbf{2 0 2 5}$ \\
\hline Ha Noi & 608,163 & 636,747 & 682,593 & 723,548 & 775,644 & 831,490 & 907,987 \\
\hline $\begin{array}{c}\text { Vinh } \\
\text { Phuc }\end{array}$ & 62,893 & 65,891 & 70,679 & 74,967 & 80,190 & 85,616 & 90,981 \\
\hline Bac Ninh & 141,838 & 155,518 & 174,406 & 193,494 & 216,413 & 241,614 & 268,541 \\
\hline $\begin{array}{c}\text { Quang } \\
\text { Ninh }\end{array}$ & 139,901 & 148,614 & 161,585 & 173,749 & 188,392 & 203,893 & 219,650 \\
\hline $\begin{array}{c}\text { Hai } \\
\text { Duong }\end{array}$ & 96,709 & 101,802 & 109,709 & 116,913 & 125,642 & 134,772 & 143,892 \\
\hline $\begin{array}{c}\text { Hai } \\
\text { Phong }\end{array}$ & 251,900 & 274,709 & 306,450 & 338,181 & 376,241 & 417,833 & 461,933 \\
\hline $\begin{array}{c}\text { Hung } \\
\text { Yen }\end{array}$ & 89,274 & 93,398 & 100,048 & 105,970 & 113,196 & 120,689 & 128,074 \\
\hline Thai Binh & 110,907 & 117,611 & 127,661 & 137,038 & 148,337 & 160,271 & 172,363 \\
\hline Ha Nam & 51,249 & 55,728 & 61,990 & 68,213 & 75,674 & 83,800 & 92,380 \\
\hline $\begin{array}{c}\text { Nam } \\
\text { Dinh }\end{array}$ & 68,584 & 70,712 & 74,675 & 77,963 & 82,097 & 86,287 & 90,259 \\
\hline $\begin{array}{c}\text { Ninh } \\
\text { Binh }\end{array}$ & 107,631 & 116,716 & 129,486 & 142,099 & 157,220 & 173,635 & 190,896 \\
\hline Ha Giang & 3,389 & 3,493 & 3,687 & 3,848 & 4,050 & 4,255 & 4,449 \\
\hline Cao Bang & 3,386 & 3,443 & 3,587 & 3,694 & 3,838 & 3,979 & 4,106 \\
\hline Bac Kan & 5,548 & 5,708 & 6,015 & 6,267 & 6,586 & 6,907 & 7,210 \\
\hline $\begin{array}{c}\text { Tuyen } \\
\text { Quang }\end{array}$ & 7,418 & 7,736 & 8,261 & 8,722 & 9,287 & 9,871 & 10,442 \\
\hline Lao Cai & 32,587 & 34,792 & 38,016 & 41,083 & 44,766 & 48,691 & 52,716 \\
\hline Yen Bai & 13,558 & 13,932 & 14,664 & 15,258 & 16,014 & 16,776 & 17,489 \\
\hline & & & & & & \\
\hline
\end{tabular}




\begin{tabular}{|c|c|c|c|c|c|c|c|}
\hline $\begin{array}{c}\text { Thai } \\
\text { Nguyen }\end{array}$ & 47,914 & 56,188 & 67,296 & 79,791 & 95,325 & 113,692 & 135,030 \\
\hline Lang Son & 12,032 & 12,353 & 12,990 & 13,505 & 14,162 & 14,823 & 15,440 \\
\hline $\begin{array}{l}\text { Bac } \\
\text { Giang }\end{array}$ & 64,844 & 69,849 & 76,987 & 83,930 & 92,255 & 101,221 & 110,552 \\
\hline Phu Tho & 55,592 & 58,139 & 62,257 & 65,918 & 70,389 & 75,022 & 79,584 \\
\hline $\begin{array}{l}\text { Dien } \\
\text { Bien }\end{array}$ & 6,373 & 6,699 & 7,209 & 7,672 & 8,233 & 8,819 & 9,403 \\
\hline Lai Chau & 11,666 & 13,288 & 15,468 & 17,820 & 20,689 & 23,980 & 27,673 \\
\hline Son La & 13,813 & 14,378 & 15,326 & 16,152 & 17,168 & 18,214 & 19,232 \\
\hline Hoa Binh & 11,714 & 12,229 & 13,072 & 13,817 & 14,729 & 15,671 & 16,595 \\
\hline $\begin{array}{c}\text { Thanh } \\
\text { Hoa }\end{array}$ & 336,574 & 354,550 & 382,350 & 407,742 & 438,490 & 470,679 & 502,878 \\
\hline Nghe An & 60,592 & 62,923 & 66,916 & 70,360 & 74,615 & 78,977 & 83,200 \\
\hline Ha Tinh & 24,664 & 24,769 & 25,494 & 25,935 & 26,616 & 27,262 & 27,787 \\
\hline $\begin{array}{l}\text { Quang } \\
\text { Binh }\end{array}$ & 22,252 & 22,885 & 24,107 & 25,106 & 26,372 & 27,650 & 28,851 \\
\hline $\begin{array}{c}\text { Quang } \\
\text { Tri }\end{array}$ & 10,174 & 10,509 & 11,117 & 11,627 & 12,266 & 12,915 & 13,533 \\
\hline $\begin{array}{c}\text { Thua } \\
\text { Thien- } \\
\text { Hue }\end{array}$ & 27,595 & 28,662 & 30,488 & 32,063 & 34,009 & 36,005 & 37,938 \\
\hline Da Nang & 84,201 & 88,109 & 94,401 & 100,010 & 106,852 & 113,949 & 120,947 \\
\hline $\begin{array}{l}\text { Quang } \\
\text { Nam }\end{array}$ & 43,899 & 50,562 & 59,499 & 69,302 & 81,344 & 95,316 & 111,211 \\
\hline $\begin{array}{l}\text { Quang } \\
\text { Ngai }\end{array}$ & 22,979 & 23,579 & 24,784 & 25,753 & 26,991 & 28,235 & 29,395 \\
\hline $\begin{array}{l}\text { Binh } \\
\text { Dinh }\end{array}$ & 353 & 362 & 381 & 396 & 415 & 434 & 453 \\
\hline Phu Yen & 112 & 118 & 127 & 136 & 146 & 157 & 169 \\
\hline $\begin{array}{l}\text { Khanh } \\
\text { Hoa }\end{array}$ & 39,538 & 40,225 & 41,929 & 43,202 & 44,903 & 46,581 & 48,089 \\
\hline $\begin{array}{l}\text { Ninh } \\
\text { Thuan }\end{array}$ & 11,889 & 12,277 & 12,985 & 13,578 & 14,321 & 15,075 & 15,794 \\
\hline $\begin{array}{l}\text { Binh } \\
\text { Thuan }\end{array}$ & 15,392 & 16,002 & 17,037 & 17,934 & 19,040 & 20,176 & 21,279 \\
\hline Kon Tum & 6,889 & 7,201 & 7,707 & 8,156 & 8,704 & 9,273 & 9,831 \\
\hline Gia Lai & 10,175 & 10,515 & 11,129 & 11,646 & 12,291 & 12,948 & 13,575 \\
\hline Dak Lak & 15,478 & 15,928 & 16,788 & 17,494 & 18,387 & 19,289 & 20,139 \\
\hline $\begin{array}{c}\text { Dak } \\
\text { Nong }\end{array}$ & 3,960 & 4,256 & 4,681 & 5,092 & 5,585 & 6,114 & 6,664 \\
\hline $\begin{array}{l}\text { Lam } \\
\text { Dong }\end{array}$ & 13,304 & 13,885 & 14,838 & 15,679 & 16,708 & 17,772 & 18,815 \\
\hline $\begin{array}{l}\text { Binh } \\
\text { Phuoc }\end{array}$ & 33,658 & 34,668 & 36,575 & 38,147 & 40,131 & 42,138 & 44,034 \\
\hline Tay Ninh & 54,019 & 56,821 & 61,189 & 65,158 & 69,971 & 75,000 & 80,015 \\
\hline $\begin{array}{c}\text { Binh } \\
\text { Duong }\end{array}$ & 298,120 & 313,554 & 337,625 & 359,494 & 386,014 & 413,719 & 441,343 \\
\hline
\end{tabular}




\begin{tabular}{|c|c|c|c|c|c|c|c|}
\hline Dong Nai & 634,731 & 662,537 & 708,124 & 748,351 & 797,598 & 848,491 & 898,388 \\
\hline $\begin{array}{c}\text { Ba Ria- } \\
\text { Vung Tau }\end{array}$ & 68,905 & 63,636 & 60,361 & 56,530 & 53,451 & 50,433 & 47,333 \\
\hline $\begin{array}{l}\text { Ho Chi } \\
\text { Minh city }\end{array}$ & 605,601 & 632,994 & 677,452 & 716,902 & 765,101 & 815,012 & 864,102 \\
\hline Long An & 110,793 & 117,284 & 127,087 & 136,184 & 147,159 & 158,723 & 170,403 \\
\hline $\begin{array}{l}\text { Tien } \\
\text { Giang }\end{array}$ & 70,045 & 73,267 & 78,469 & 83,099 & 88,749 & 94,607 & 100,378 \\
\hline Ben Tre & 21,553 & 22,206 & 23,434 & 24,450 & 25,729 & 27,023 & 28,248 \\
\hline Tra Vinh & 17,312 & 18,426 & 20,072 & 21,625 & 23,493 & 25,474 & 27,496 \\
\hline $\begin{array}{l}\text { Vinh } \\
\text { Long }\end{array}$ & 8,732 & 9,005 & 9,511 & 9,932 & 10,461 & 10,997 & 11,505 \\
\hline $\begin{array}{l}\text { Dong } \\
\text { Thap }\end{array}$ & 24,458 & 25,096 & 26,379 & 27,411 & 28,730 & 30,055 & 31,291 \\
\hline An Giang & 21,382 & 21,632 & 22,426 & 22,980 & 23,755 & 24,508 & 25,162 \\
\hline $\begin{array}{l}\text { Kien } \\
\text { Giang }\end{array}$ & 53,808 & 56,128 & 59,951 & 63,315 & 67,437 & 71,693 & 75,860 \\
\hline Can Tho & 40,651 & 42,891 & 46,328 & 49,483 & 53,299 & 57,303 & 61,321 \\
\hline $\begin{array}{l}\text { Hau } \\
\text { Giang }\end{array}$ & 4,121 & 4,244 & 4,478 & 4,670 & 4,913 & 5,158 & 5,390 \\
\hline Soc Trang & 7,673 & 7,719 & 7,957 & 8,108 & 8,334 & 8,550 & 8,729 \\
\hline Bac Lieu & 8,545 & 8,738 & 9,154 & 9,480 & 9,903 & 10,325 & 10,713 \\
\hline Ca Mau & 10,097 & 10,232 & 10,625 & 10,905 & 11,291 & 11,668 & 12,000 \\
\hline Grand & $4,863,109$ & $5,118,069$ & $5,518,073$ & $5,887,049$ & $6,340,115$ & $6,821,503$ & $7,331,133$ \\
\hline $\begin{array}{c}\text { National } \\
\text { Target }\end{array}$ & $4,852,954$ & $5,106,651$ & $5,483,135$ & $5,868,063$ & $6,304,246$ & $6,779,126$ & $7,288,525$ \\
\hline
\end{tabular}

\section{Discussion}

The economic development and energy consumption are two core variables effect on Vietnamese energy efficiency. Based on the actual energy efficiency situation, the Vietnam government has improved the energy efficiency for 15 years, started from 2006 with the Vietnam National Energy Efficiency Program. The new era of the Vietnam energy efficiency strategy started in early of 2019 and will implement continuously until 2030. Three main aspects, i.e., policy, technology and industry are main coordinators for improvement of the feature of the Vietnam energy efficiency. It also confirms that provinces play an important actor for achievement of the national energy efficiency target, therefore, the allocation of the national target to provinces is need.

The allocation mechanism proposed mainly considers the regional local economic development level, energy consumption historical trend and tendency of economic development combined with the required energy consumption. Based on the calculated energy consumption requirement and analysis of regional economic structure, this work suggest a mixture of economic-oriented and energy-oriented method to build up The 5-year socio-economic development Plan in terms of sustainable development and energy consumption reform for each province from 2021 to 2025. The provincial government can distinguish, anticipate and obligate indicators to restrict energy consumption as well as evaluate the province's energy efficiency within the possibility. It also reduces the pressure on energy saving for low developed provinces in the short term and finally archive the long-term goal of Vietnam's energy secure strategy.

\section{Conclusion}


Understanding the potentiality of energy efficiency is useful for the harmonious and sustainable development between the economy and energy systems. In this study, provincial and national data are collected to analyze the energy efficiency levels in Vietnam. The trends of national and regional economic development and energy consumption are used to predict the energy consumption requirement need for economic development in the period of 2019 - 2025. It also reveals that the energy saving allocation in Vietnam is uneven. Combined with the different GDP development and energy consumption levels, the target regions of energy efficiency analysis are newly divided via a cluster analysis method. The provinces are classified into 7 clusters. Based on this, a quantitative calculation method is employed to estimate the amount of saving energy of each province. The results show that 33 provinces included in the cluster 1, 2, 3, 4 and 6 are heavy contribution. Among them, the provinces in the cluster 2 and 3 need to focus on the industry sector in their energy saving policy. The cluster 7 included the under-developed provinces can learn development's experiences of the provinces in the cluster 1, 2, 3 and 4 to find the best way of their future development.

Acknowledgments: This study used a partial supported data from the World Bank in Vietnam.

Conflicts of Interest: The authors declare no conflicts of interest.

\section{References}

1. Vietnam National Program of Energy Efficiency in the period of 2019 - 2019 (in Vietnamese). Available online:

http://vanban.chinhphu.vn/portal/page/portal/chinhphu/hethongvanban?class id=2\&mode=detail\&docu ment id=196453 (accessed on 03 May 2019).

2. Synergy operational schemes of saving energy and reducing pollution in 12th Five-Year Plan (in Chinese). Available online: http://www.gov.cn/zwgk/2011-09/07/content;1941731.htm (accessed on 03 May 2019)

3. Shock, R. The UK Energy Efficiency Best Practice Program. Available online: http://www.un.org/events/energy2000/speaker/shock/shock.ppt (accessed on 7 July 2018).

4. ETSU, 1999. Industrial Sector Carbon Dioxide Emissions: Projections and Indications for the UK, 1990 2020. See discussion of this report in ETSU, AEA Technology, 2001. Climate Change Agreements - Sectoral Energy Efficiency Targets (version 2). Available online: http://www.defra.gov.uk/environment/ccl/pdf/etsu-analysis.pdf(accesed on 17 December 2018).

5. Phylipsen, G.J.M.; Bode, J.W.; Blok, K.; Merkus, H. and Metz, B. A Triptych Sectoral Approach to Burden Differentiation; GHG Emissions in the European Bubble. ENERG POLICY. 1998b 26, 929-943.

6. Phylipsen,G.J.M. and Höhne, N. The Triptych Approach, Presentation for Center for Clean Air Policy Dialogue on Future International Actions to Address Global Climate Change. 2004.

7. Punj, G.; Stewart, D.W. Cluster analysis in marketing research: Review and suggestions for application J Mark Res, 1983, 20, 134-148.

8. Soares, J.O.; Marques, M.M.L. and Monteiro, C.M.F. A multivariate methodology to uncover regional disparities: A contribution to improve European Union and governmental decisions Eur J Oper Res, 2003 145, 121-135.

9. Del Campo, C.; Monteiro, C. and Soares, J.O. The European regional policy and the socio-economic diversity of European regions: A multivariate analysis. Eur J Oper Res 2008, 187, 600-612.

10. Ward, J.H. Hierarchical grouping to optimize an objective function. J Am Stat Assoc. 1963, 58, 236-244.

11. Lloyd, S.P. Least squares quantization in PCM. IEEE Transactions on Information Theory 1982, 28, 129137. 